\title{
The Effect Of Non-Performing Financing (NPF) On Earnings Management Practices In Islamic And Conventional Bank
}

\author{
Erika Eriyanti ${ }^{1}$, Rianti Pratiwi $^{2}$, Muhammad Doddy $^{3}$
}

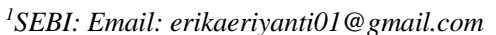 \\ ${ }^{2}$ SEBI Lecturer \& Doctoral Candidate RMIT University, Email:rianti.affandi@gmail.com \\ ${ }^{3}$ SEBI Lecturer \& Doctoral Candidate AeU Malaysia Email: muhammad.doddy@sebi.ac.id
}

\begin{abstract}
This study aims to examine the effect of Non-Performing Financing (NPF) to Earnings Management Practices in Islamic Bank and Conventional Bank. Earnings management procedures are still regarded legal when they do not conflict with General Accepted Accounting Principles (GAAP), but when viewed from an Islamic perspective, particularly in Islamic business ethics and sharia management, earnings management practices are regarded to be incompatible with the principles contained in Islamic business ethics and sharia management.The data collection of this research uses documentation technique from financial reports of Islamic bank and conventional bank. The analytical method which is used in this study is panel data regression. This study found that the Non-Performing Financing (NPF) have a significant positive effect with Earnings Management. For the implication, investors and other financial statements customers are anticipated to be more cautious in evaluating financial statements. For business institutions, especially sharia business institutions, the principles of Islamic business ethics should always be instilled in carrying out their operations.
\end{abstract}

Keywords: Non-Performing Financing, Earnings Management, General Accepted Accounting Principles

\section{INTRODUCTION}

Every year or in one accounting period, all profit orientied business entities must announce their financial performance results in the form of company financial statements. One of the benchmarks for assessing whether a business is successful or not is the amount of profit achieved. In this case accounting has an important role in assessing the performance of a company. Statement of Financial Accounting Concepts (SFAC) Number 1 states that the purpose of financial statements is to provide information that is useful for investors, creditors, and other users (FASB 1978).

In financial reporting, the banking industry should use financial reports that are quality, understandable, relevant, materiality, reliability as a medium to provide information about financial position and company performance. Managerial parties are motivated to increase profits to attract the attention of investors. Preparation of financial statements using accrual basis calculation because it is more rational and fairer in reflecting the company's financial condition in real terms (Wahyuningsih \& Pujiati, 2016). The use of accrual basis provides flexibility to the management in choosing accounting methods as long 
Jurnal Ekonomi dan Perbankan Syariah

Vol. 7. No.1, April 2019: 22-36, ISSN (cet): 2355-1755 | ISSN (online): 2579-

6437

\section{| 23}

as they do not deviate from the applicable financial accounting standard rules so that they can affect the amount of profit. The size of profits greatly affects the judgment of investors so that when profits do not look good, companies often outsmart profits by practicing earnings management.

Scott (2006) states that earnings management is the selection of accounting policies by managers of existing accounting standards and can naturally maximize their utility or market value of the company. Earnings management occurs when management uses certain decisions in financial statements and transactions to change financial statements as a basis for company performance that aims to mislead owners or shareholders or to influence contractual results that rely on reported accounting figures (Healy \& Wahlen, 1999).

Earnings management is carried out intentionally and with certain objectives, within the limits of General Accepted Accounting Principles (GAAP), to lead to a desired level of profits reported by management. Earnings management is a form of management intervention in the preparation of financial statements. Interventions carried out through the manipulation of accounting numbers reported raised accounting scandals, such as in the case of off-balance sheet transactions, including Enron Energy in 2000, cases of increasing Xerox revenues in 1997-2000 and so on. In Indonesia, this has also been an issue, such as in the case of the Kimia Farma mark up in 2001 and the 2002 Lippo Bank double bookkeeping (Inggarwati \& Kaudin, 2010).

Earnings management, lately is a common phenomenon that occurs in a number of companies. Practices carried out to influence profit figures can occur legally or illegally. Legal practice in earnings management means that efforts to influence earnings figures do not conflict with financial reporting rules in the General Acceptable Accounting Principles (GAAP), especially in Accounting Standards, namely by utilizing opportunities to make accounting estimates, make changes in accounting methods, and shift period of income or cost. The earnings management carried out illegally (also called financial fraud), is done in ways that are not permitted by the General Acceptable Accounting Guidelines (GAAP), namely by reporting income or cost transactions fictitiously by adding (mark up). ) or mark down the value of the transaction, or maybe by not reporting a number of transactions, so that it will generate profits at the desired value or desired level.

The Fatwa of the Dewan Syariah Nasional No.14 / DSN-MUI / IX / 2000 concerning the Business Distribution System in Islamic Financial Institutions states that the benefit of recording (financial statements) should be used as a base accrual system, although it also states that the distribution of business results should be determined on the basis of acceptance that really happened (Cash Basis). Based on PSAK No. 101 regarding Accounting for Islamic Banks, the basic assumption is taken of the accounting concept of Islamic banks as the basic assumptions of the general financial accounting concept, namely the going 
24 | Erika Eriyanti, Rianti Pratiwi, Muhammad Doddy: The Effect of Non-Performing Financing (NPF) on Earnings Management Practices in Islamic and Conventional Bank

concern concept and accrual basis. But in sharia, even if the muamalah is done not in cash, the recording must be correct.

In connection with the controversy regarding earnings management, seen in an ethical perspective, earnings management is one of the important problems in the business world. The implementation of management activities raises questions about ethics for management because it has an influence on managers and their companies (Burns and Merchant, 1990) (Kawedar, 2005). Ethics in Islam advocates for humans to bring peace, honesty and justice. Ethics of work in Islam also teaches that humans in carrying out their work are carried out honestly and trustworthily (not taking something that is not their right, not cheating, objective in judging) and not violating sharia principles.

Funds disbursed by banks in the form of credit are the largest source of funds for banks, so that in lending, banks must face credit risk which causes the credit to become problematic. Non-Performing Financing (NPF) shows the ability of bank management in managing non-performing loans provided by banks, so that the higher the NPF, the worse the quality of bank credit, which will increase the number of problem loans.

The existence of earnings management actions can also be influenced by the NPF ratio because this can reduce the profitability of the bank. The profitability of a banking company shows the income that the company can produce in one or every period. The high profitability of a bank can show that most of the bank's performance can be said to be good, because it is assumed that the bank has operated effectively and efficiently and allows the bank to expand its business. NPF is a proxy for non-performing loans where the higher the NPF ratio, the bank profits will decrease, on the contrary if the lower the NPF ratio, the bank profits will increase.

NPL shows that the ability of bank management in managing nonperforming loans provided by banks. Based on Financial Accounting Standards No. 31 (Revised 2000), Non-performing loans are generally loaning whose payment of principal installments and or interest has passed ninety days or more after maturity or credit for which payment is timely is very doubtful. The current NPL allowed by Bank Indonesia is a maximum of 5\%, if it exceeds 5\%, the bank is not in good health. NPL is considered as a practice of earnings management, as stated by Zahara and Sylvia (2009), which proves empirically that banks tend to practice earnings management by increasing profits if profits are lower than desired. Sapariyah (2009) states that NPL has an effect on banking profit growth in Indonesia (Fricilia \& Lukman, 2015).

How Islam views the practice of earnings management? Is it something bad, reasonable, whether permissible or not, legal or illegal? And how the influence of the ratio of NPF (Non-Performing Financing) in earnings management practices?

Many factors trigger earnings management, one of which is NPF. In addition, the practice of earnings management reaps various kinds of controversy. Research on the practice of earnings management in an Islamic perspective is still sparse, this is an interesting topic for writers to conduct research. 
Jurnal Ekonomi dan Perbankan Syariah

Vol. 7. No.1, April 2019: 22-36, ISSN (cet): 2355-1755 | ISSN (online): 2579-

6437

| 25

\section{LITERATURE REVIEW}

\section{EARNINGS MANAGEMENT}

\section{Definition of Earnings Management}

According to Fischer and Rosenzweig (1995) earnings management is defined as the actions of managers by presenting reports that increase or decrease profit for the current period from business units that are the responsibility without causing an increase or decrease in the unit's economic profitability (Padmantyo, 2010)

According to Scott (2006), there is a motivation for companies to conduct earnings management, namely Other Contractual Motivations, Communicating Information to Investors, Political Motivations, Taxation Motivations, Changes of Chief Executive Officers (CEOs), Initial Public Offerings.

The practice of earnings management is not only influenced by the above factors, it is also motivated by several reasons. The reason for earnings management is that managers can determine when time will do earnings management through their policies. Another reason is the manager's decision to implement an accounting policy that must be applied by a company. In addition, the efforts of managers to replace or change a particular accounting method from the many methods that can be chosen that are available and recognized by existing accounting bodies are also the reason (Marzuqi \& Latif, 2010).

In its implementation the pattern of earnings management has several patterns, according to Scott (2000) the forms of earnings management carried out by managers include income minimization, income maximation and income smoothing (Rama, 2010).

\section{Earning Management as Cheating}

The freedom to choose and use accounting methods and procedures as needed becomes a trigger for earnings management. Some parties state that earnings management activities are considered fraudulent if the company records sales before it can be realized and records fictitious sales. This means that the company faked actual sales transactions that have not or have never been done. Another activity is to postpone the date of proof of purchase made to regulate the level of profit as desired by the company manager. Another activity that is considered cheating is recording fictitious inventories to increase asset value so as to improve the company's solvability performance (Sulistyanto, 2008) 
26 | Erika Eriyanti, Rianti Pratiwi, Muhammad Doddy: The Effect of Non-Performing Financing (NPF) on Earnings Management Practices in Islamic and Conventional Bank

\section{Earnings Management is Not Part of Cheating}

Accounting does not require a company to always recognize and record a transaction in accordance with the actual event. This means that the company does not always inform the actual profit earned during a certain period in its financial statements (Sulistyanto, 2008).

1) Conservative accounting, is an accounting process to recognize and record a transaction carefully so that the company does not experience difficulties in the future.

2) Aggressive accounting, is an accounting process to recognize and record a transaction exploratively.

\section{Earnings Management Measurement Models}

\section{Healy model}

Healy Model (1985) tests earnings management by comparing the average total accruals across all variables in the division of earnings management. The Healy study is different from most other earnings management studies because it predicts that systematic earnings management occurs in each period. The dividing variable divides the sample into three groups, with income predicted to be managed upwards in one group and downwards in the other two groups. The conclusions are then made through the average paired accrual comparison in the group where income is predicted to be managed upward with the total accrual average for each group where income is predicted to be managed downward. This approach is equivalent to treating a set of observations where income is expected to be managed upwards as an estimation period and a set of observations where income is expected to be managed downward as a period of events.

\section{Jones model}

Jones (1991) proposes a model that simplifies the notion that nondiscretionary accruals are constant. The model tries to control the effects of changes in the company's economic environment on nondiskritioner accruals. Dechow et al. (1995) explained that the results of the Jones Model calculation showed that the model succeeded in explaining about a quarter of the total accrual variation. The assumption implicit in the Jones model is that income is not discretionary. If income is managed through discretionary income, then the Jones Model will delete a portion of income managed from a discretionary accrual proxy.

\section{Industrial Model}

Dechow and Sloan (1991) compiled a earnings management measurement model known as the Industry Model. Similar to the Jones Model, the Industrial Model simplifies the notion that nondiscretionary accruals are constant over time. However, instead of trying to directly model nondiskritioner accrual determinants. The Industrial Model assumes that variations in non- 
Jurnal Ekonomi dan Perbankan Syariah

Vol. 7. No.1, April 2019: 22-36, ISSN (cet): 2355-1755 | ISSN (online): 2579-

6437

\section{| 27}

discretionary accrual determinants are common across firms in the same industry.

\section{Earnings Management in Islam}

Djakman (2003) states that earnings management carried out through accrual management is not the same as earnings manipulation. Earnings management is carried out by utilizing the internal weaknesses of accrual accounting policies and is still within the corridor of generally accepted accounting principles. While earnings manipulation is an act of violation of generally accepted accounting principles to produce the company's financial performance according to the interests of managers or companies (Marzuqi \& Latif, 2010).

In a study conducted by Marzudi and Latif (2010), it was revealed that the practice of earnings management was not in accordance with what was guided by the teachings of Islam. In line with the research of Muliasari and Dianati (2014) which suggests that earnings management is not in accordance with Islamic business ethics. Beekun and Badawi (2005) explain that for a Muslim, Islam is a way of life, so that in carrying out its business activities must adhere to Islamic values that are guided by the Koran and hadith (Muliasari \& Dianati, 2014).

According to Muhammad (2005), there are several principles which at least must be attached or integrated in Islamic accounting. The principles are the principle of accountability, the principle of justice and the principle of truth.

\section{NON-PERFORMING FINANCING (NPF)}

According to KBBI, Non-Performing Financing (NPF) is non-performing loans consisting of loans classified as substandard (substandard), doubtful doubt) and loss (loss). If it is associated with the NPF ratio, the Non-Performing Financing (NPF) category is financing in collectibility 3, 4, and 5 (Ifham, 2016).

Non-Performing Financing (NPF) is known by calculating the amount of problematic financing to total financing or in other words in conventional banks Non-Performing Loans (NPLs) are calculated by comparing the number of nonperforming loans with total credit (credit amount). NPL can be formulated as follows (Rivai, 2007):

$$
N P F=\frac{\text { Non }- \text { Performin Financing }}{\text { Total Financing }} \times 100
$$

The lower the NPF or NPL, the higher the profit increases. If the higher the NPF level, the bank will suffer losses due to the rate of return on bad credit. Relationship between Non-Performing Financing (NPF) and Earnings Management Practices

Robb (1998) in Zahara and Sylvia (2009) proved empirically that banks tend to practice earnings management by increasing profits if profits are lower than desired. The assessment of the risk profile can also motivate managers to 
28 | Erika Eriyanti, Rianti Pratiwi, Muhammad Doddy: The Effect of Non-Performing Financing (NPF) on Earnings Management Practices in Islamic and Conventional Bank

do earnings management. Sapariyah (2009) states that NPL affects the growth of banking profits in Indonesia. Based on this, the following hypothesis is formulated:

"Non-Performing Financing (NPF) has a significant positive effect on earnings management practices."

\section{METHODOLOGY}

This research uses quantitative methods. The population used is all commercial banks in Indonesia, both conventional and sharia. In addition, the research technique in this study used purposive sampling with the criteria of sharia commercial banks with the most assets and the largest and most extensive office network and conventional banks included in the list of ten banks with the largest assets. The data sources used are quarterly financial statements of Bank Syariah Mandiri and Bank Mandiri in 2013-2017. The static analysis method used in this study is panel data regression analysis

\section{RESULTS \& DISCUSSION}

\section{DESCRIPTIVE STATISTICS}

Based on the results of descriptive statistics, it can be seen that from the 2013-2017 Bank Syariah Mandiri and Bank Mandiri quarterly reports, earnings management has a minimum value of -0.039335 , a maximum value of 0.169267 , and also a median value of 0.044854 , and a standard deviation value of 0.064183 . With an average value of 0.059037 while for the independent variable it can be seen that the average value for NPF is 3.860250 . The median value for NPF is 3.850000. The maximum NPF value is $6,900,000$. The minimum value of NPF is 1.610000 with a standard deviation of 1.612754 .

Of the two variables, it shows that earnings management has the smallest standard deviation value. This shows the more homogeneous data that exists, so the data with standard deviation values are getting smaller and more accurate and show the distribution of data that is getting closer to normality.

Skewness shows the value of data variable tendencies. The value of skewness for earnings management variable is 0.295055 , while the value of skewness for NPF is 0.118473 . If the value of skewness less than 0 , data distribution deviates from left.

Kurtosis, the value of kurtosis is used to show the normality of the data provided that the data is normally distributed if the value is 3 . In table 4.1 it is seen that the value of kurtosis in the earnings management variable is 1.781172 while the NPF has a kurtosis value of 1.841316 . When compared to the results, the NPF variable has a more normal distribution than the earnings management variable. 
Jurnal Ekonomi dan Perbankan Syariah

Vol. 7. No.1, April 2019: 22-36, ISSN (cet): 2355-1755 | ISSN (online): 2579-

6437

| 29

Table 1: Descriptive Statistics Results

\begin{tabular}{lcc}
\hline & EARNINGS MANAGEMENT & NPF \\
\hline Mean & 0.059037 & 3.860250 \\
\hline Median & 0.044854 & 3.850000 \\
\hline Maximum & 0.169267 & 6.900000 \\
\hline Minimum & -0.039335 & 1.610000 \\
\hline Std. Dev. & 0.064183 & 1.612754 \\
\hline Skewness & 0.295055 & 0.118473 \\
\hline Kurtosis & 1.781172 & 1.841316 \\
\hline Observations & 40 & 40 \\
\hline
\end{tabular}

\section{CLASSICAL ASSUMPTION TEST RESULTS}

\section{Normality test}

Normality test is done by looking at the probability value of Jarque-Bera. If the JB probability ( $\mathrm{p}$-value) gets closer to zero, then the data is not normally distributed. Conversely, if the probability ( $p$-value) of Jarque-Bera exceeds the probability (0.05), the conclusion is that the data is normally distributed.

The results of Jarque-Bera testing using the Eviews 9 application can be seen in the graph below:

Table 2: The Results of Jarque-Bera Testing

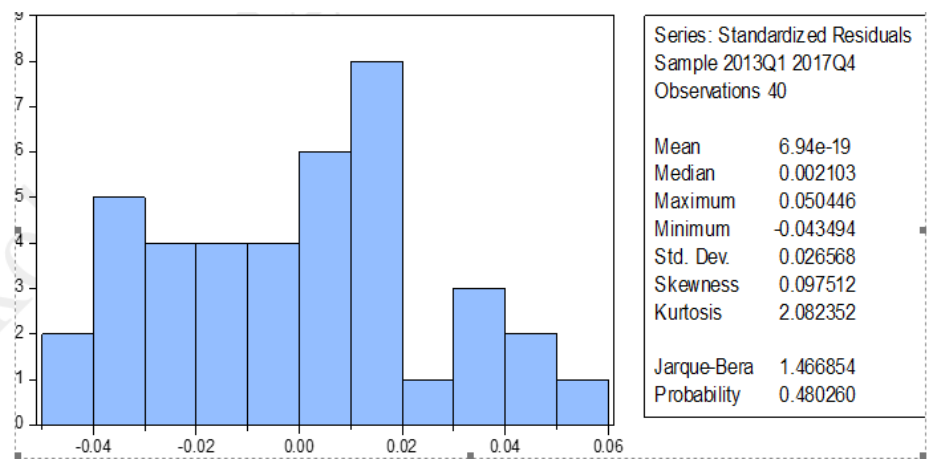

The output of the graph above shows that Jarque Bera's p-value is $0.480260>0.05$. Thus, accepting $\mathrm{H} 0$ and rejecting $\mathrm{H} 1$, which means the error follows the normal distribution function and classic assumptions about normality in the Fixed Effects Model. 
30 | Erika Eriyanti, Rianti Pratiwi, Muhammad Doddy: The Effect of Non-Performing Financing (NPF) on Earnings Management Practices in Islamic and Conventional Bank

\section{HYPOTHESIS TEST RESULTS}

After a series of tests to find out which model is the best to use between Common Effect Model (CEM), Fixed Effect Model (FEM), and Random Effect Models REM), it is known that the FEM model is the best model and is more suitable to be used in this study.

The following is the estimation result of the regression equation Fixed Effect Model (FEM):

Tabel: 3 The Result of Fixed Effect Model (FEM)

\begin{tabular}{lrrrr}
\hline \hline \multicolumn{1}{c}{ Variable } & Coefficient & \multicolumn{1}{c}{ Std. Error } & t-Statistic & Prob. \\
\hline \multicolumn{1}{c}{ C } & 0.021373 & 0.015804 & 1.352392 & 0.1845 \\
NPF & 0.009757 & 0.003939 & 2.477227 & 0.0179 \\
\hline \hline \multicolumn{5}{c}{ Effects Specification } \\
\hline \hline Cross-section fixed (dummy variables) & & \\
\hline \hline R-squared & 0.828650 & Mean dependent var & 0.059037 \\
Adjusted R-squared & 0.819388 & S.D. dependent var & 0.064183 \\
S.E. of regression & 0.027277 & Akaike info criterion & -4.293538 \\
Sum squared resid & 0.027528 & Schwarz criterion & -4.166872 \\
Log likelihood & 88.87076 & Hannan-Quinn criter. & -4.247740 \\
F-statistic & 89.46629 & Durbin-Watson stat & 0.883005 \\
Prob(F-statistic) & 0.000000 & & \\
\hline \hline
\end{tabular}

Source: Output FEM with Eviews 9

The following is the estimation result of the regression equation Fixed Effect Model (FEM):

From the results of regression testing using the Fixed Effect Model (FEM) above, the regression equation is obtained as follows:

$$
\mathrm{Y}=\alpha+\beta . \mathrm{X} \rightarrow \text { Earnings Management }=0.021373+0.009757 . \mathrm{NPF}
$$

The results above show that the independent variable, Non-Performing Financing (NPF) has a positive effect on earnings management practices.

The coefficient of determination test is used to measure how far the model's ability to explain the variation of the independent variable on the dependent variable. This number can measure how close the regression line is to estimation with the actual data. If the value of the coefficient of determination equals zero $\left(\mathrm{R}^{2}=0\right)$, it means that the variation of $\mathrm{Y}$ cannot be explained at all by $X$. Whereas if $R^{2}=1$, it means that the overall variation of $Y$ can be explained by $X$. The result of the test coefficient of determination $\left(R^{2}\right)$ is as follows:

Tabel 4: The Result of Determination Coefficient

\begin{tabular}{lllr}
\hline \hline & & & \\
R-squared & 0.828650 & Mean dependent var & 0.059037 \\
Adjusted R-squared & 0.819388 & S.D. dependent var & 0.064183 \\
S.E. of regression & 0.027277 & Akaike info criterion & -4.293538
\end{tabular}


Jurnal Ekonomi dan Perbankan Syariah

Vol. 7. No.1, April 2019: 22-36, ISSN (cet): 2355-1755 | ISSN (online): 2579-

6437

\section{| 31}

\begin{tabular}{lllr} 
Sum squared resid & 0.027528 & Schwarz criterion & -4.166872 \\
Log likelihood & 88.87076 & Hannan-Quinn criter. & -4.247740 \\
F-statistic & 89.46629 & Durbin-Watson stat & 0.883005 \\
Prob(F-statistic) & 0.000000 & & \\
\hline
\end{tabular}

\section{Source: Output of Eviews 9}

The test results of the coefficient of determination in the study (Table 4) is 0.828650 . This figure reflects the proportion of the variation of the independent variable on the dependent variable which can be explained using independent variables. The conclusion is that 0.828650 dependent variable variations (earnings management) can be explained using independent variables (NPF). The coefficient of determination in this study was $82.86 \%$. These results indicate that the variation of the dependent variable (earnings management) of $82.86 \%$ can be explained by its independent variable (NPF) while the remaining $17.14 \%$ is explained by other variables not explained in this study.

The results showed that Non-Performing Financing had a significant positive effect on earnings management practices with a significance value of $0.0179<0.05$ which means that the higher the NPF value, the higher the practice of earnings management. This is done to maintain the image of the company that makes investors invest in the company. These results are consistent with the research of Misman and Ahmad (2011), Abdullah et. al (2014), and Taktak et. al (2010) which proves that NPL (NPF) has a significant influence on earnings management. In contrast to the research conducted by Kartikasari (2011) and Zahara (2009) which proves that NPL does not affect the practice of earnings management. NPLs that have no effect on earnings management are suspected because the role of corporate governance in banking companies has been carried out well.

\section{CONCLUSION}

Earnings management practices are still considered legal when not in conflict with General Accepted Accounting Principles (GAAP), but if viewed from an Islamic perspective, especially in Islamic business ethics and sharia management, the practice of earnings management is a practice that is deemed inconsistent with the values contained in Islamic business ethics and sharia management. The practice of earnings management is also prohibited whatever its motivation because it tends to lead to practices that benefit themselves.

Based on the testing, analysis and discussion described earlier, partially the Non-Performing Financing (NPF) variable has a significant positive effect on earnings management practices at Bank Syariah Mandiri and Bank Mandiri based on Bank Syariah Mandiri quarterly financial statements and Bank Mandiri 
32 | Erika Eriyanti, Rianti Pratiwi, Muhammad Doddy: The Effect of Non-Performing Financing (NPF) on Earnings Management Practices in Islamic and Conventional Bank

during 2013 to 2017. Non-Performing Financing (NPF) has a significant positive effect on management at Bank Syariah Mandiri and Bank Mandiri means H1 is accepted. This means that the greater the NPF value, the greater the earnings management.

For managerial implication, it is expected that investors and other users of financial statements will be more careful in assessing financial statements. For business people should always instill the principles of Islamic business ethics in carrying out their activities in order to get the blessing of the world and the hereafter.

Suggestions for further research are expected to improve the limitations of this study. Further research should use annual financial reports with notes to financial statements, so that all information needed for research is available in full. Also, further research is expected to increase the number of samples and also explore other factors that are expected to influence earnings management practices such as the existence of bonus plans for managers, Adequacy Ratio (CAR), Return On Equity (ROE) and other variables in Good Corporate Governance (GCG). ) so that the models obtained are better.

\section{BIBLIOGRAPHY}

Al Qur'an dan Hadits

Al Nadawi, A. A. (1994). Al-Qawa'id al Fiqhiyyah. Damaskus: Dar al-Qalam.

Anggraeni, M. D. (2011). Agency Theory dalam Perspektif Islam. Jurnal Hukum Islma (JHI) Vol. 9 No. 2.

Anggraeni, R. M., \& Hadiprajitno, P. B. (2013). Pengaruh Struktur Kepemilikan Manajerial, Ukuran Perusahaan, dan Praktik Corporate Governance terhadap Manajemen Laba. Diponegoro Journal of Accounting Vol. 2 No. 3.

Arisandy, Y. (2015). Manajemen Laba dalam Prespektif Islam. MIZANI Vol. 25 No. 2.

Beekun, R. I. (1996). Islamic Business Ethics. Herndon: International Institute of Islamic Thought.

Beekun, R. I., \& Badawi, J. A. (2005). Balancing Ethical Responsibility among Multiple Organizational Stakeholders: The Islamic Perspective . Journal of Business Ethics.

Chwastiak, M. (1999). Deconstructing The Principal Agent Model. The Bottom Criticsl Perspective on Accounting.

Dendawijaya, L. (2005). Manajemen Perbankan. Jakarta: Ghalia Indonesia.

Effendi, M. A. (2009). The Power of Good Corporate Governance: Teori dan Implementasi. Jakarta: Salemba Empat.

Enekwe, C. I., Agu, C. I., \& Eziedo, K. N. (2014). The Effect of Financial Leverage on Financial Performance: Evidence of Quoted Pharmaceutical Companies in Nigeria. IOSR Journal of Economics and Finance (IOSR-JEF) Vol. 5 No. 3, 19. 
Jurnal Ekonomi dan Perbankan Syariah

Vol. 7. No.1, April 2019: 22-36, ISSN (cet): 2355-1755 | ISSN (online): 2579-

6437

| 33

Faradila, A., \& Cahyati, A. D. (2013). Analisis Manajemen Laba pada Perbankan Syariah. JRAK, 4 No. 1.

Fricilia, \& Lukman, H. (2015). Analisis Faktor-Faktor yang Memengaruhi Praktik Manajemen Laba pada Industri Perbankan di Indonesia. Jurnal Akuntansi Vol. XIX No.1.

Harahap, S. S. (1996). Akuntansi Islam. Jakarta: Bumi Aksara.

Healy, P. M., \& J.M., W. (1999). A Review of Earnings Management Literature and Its Implications for Standard Setting. Accounting Horizons 13.

Heikal, M., Khaddafi, M., \& Ummah, A. (2014). Influence Analysis of Return On Asset (ROA), Return On Equity (ROE), Net Profit Margin (NPM), Debt To Equity Ratin (DER), Against Corporate Profit Growth in Automotive in Indonesia Stock Exchange. International Journal of Academic Research in Business and Social Sciences Vol. 4. No. 12, 103.

Ifham, A. (2016). Strategi Penanganan Pembiayaan Bermasalah. Depok: Heryana Media.

Ikatan Bankir Indonesia. (2015). Bisnis Kredit Perbankan. Jakarta: Gramedia Pustaka Utama.

Inggarwati, K., \& Kaudin, A. (2010). Persepsi Etis Pelaku Akuntansi terhadap Praktik Manajemen Laba Berdasarkan Profesi Akuntansi dan Jender. Jurnal Manajemen Teori dan Terapan Tahun 3 No.3.

Jensen, M. C., \& W.H. Meckling. (1976). Theory of The Firm: Managerial Behavior, Agency Cost and Ownership Structure. Journal of Financial Economics 3.

Kawedar, W. (2005). Sikap Etis Akuntan dan Pengguna Jasa Akuntan terhadap Praktik Manajemen Laba. Jurnal Akuntansi \&Auditing Vol. 1 No. 2.

Lartey, V. C., Antwi, S., \& Boadi, E. K. (2013). The Relationship between Net Interest Margin and Return On Assets of Listed Banks in Ghana. Research Journal of Finance and Accounting Vol. 4 No. 16, 73.

Marzuqi , A. Y., \& Latif, A. B. (2010). Manajemen Laba dalam Tinjauan etika Bisnis Islam. JURNAL DINAMIKA EKONOMI \& BISNIS Vol. 7 No. 1.

Marzuqi, A. Y., \& Latif, A. B. (2010). Manajemen Laba dalam Tinjauan Etika Bisnis Islam. Jurnal Dinamika Ekonomi dan Bisnis Vol. 7 No. 1, 6.

Mashud, A. (2006). Manajemen Risiko Strategi Perbankan dan Dunia Usaha Menghadapi Tantangan Global Bisnis. Jakarta: PT Grafindo Persada.

Mirdhani, L. P., \& Budiyanto. (2014). Analisis Rasio CAMEL untuk Menilai Kesehatan Bank pada Perusahaan LQ-45 di BEI. Jurnal Ilmu \& Riset Manajemen VOL. 3 No. 5.

Muhammad, \& Fauroni, L. (2002). Visi Al-Qur'an tentang Etika dan Bisnis. Jakarta: Salemba Diniyah.

Muliasari, I., \& Dianati, D. (2014). Manajemen Laba dalam Sudut Pandang Etika Bisnis Islam. Jurnal Akuntansi dan Keuangan Islam Vol. 2 No. 2, 160.

Nachrowi, N. D., \& Usman, H. (2006). Pendekatan Populer dan Praktis Ekonometrika untuk Analisis Ekonomi dan Keuangan. Jakarta: Lembaga Penerbit Fakultas Ekonomi Universitas Indonesia. 
34 | Erika Eriyanti, Rianti Pratiwi, Muhammad Doddy: The Effect of Non-Performing Financing (NPF) on Earnings Management Practices in Islamic and Conventional Bank

Otoritas Jasa Keuangan. (2017). Laporan Profil Industri Perbankan - Triwulan 2017. Jakarta: Otoritas Jasa Keuangan.

Padmantyo, S. (2010). Analisis Manajemen Laba Pada Laporan Keuangan Perbankan Syariah (Studi pada Bank Syariah Mandiri dan Bank Muamalat Indonesia). BENEFIT Jurnal Manajemen dan Bisnis Vol. 14 No. 2, 54.

Putra, S. J., \& Durachman, Y. (2009). Etika Bisnis dan Hak Kekayaan Intelektual. Jakarta: Lembaga Penelitian UIN Jakarta.

Putri, D. R. (2016). Pengaruh Non Performing Loan dan Kualitas Aktiva Produktif terhadap Profitabilitas pada PT. BPR Mutiara Nagari. Jurnal Ekonomi \& Bisnis Dharma Andalas Vol. 18 No. 2.

Raharjo, P. G., Hakim, D. B., Manurung, A. H., \& Maulana, T. N. (2014). The Determinant of Commersial Bank's Interest Margin in Indonesia: An Analysis of Fixed Effect Panel Regression. International Journal of Economics and Financial Issues Vol. 4 No. 2, 301.

Rahayu, A. (2009). Paper Deskriptif Model Jones (1991).

Rama, R. S. (2010). Manajemen Laba (Earning Management) dalam Perspektif Etika Hedonisme. Jurnal El Muhasaba Vol. 1 No. 2, 126.

Riduwan, A. (2010). Etika dan Perilaku Koruptif dalam Praktik Manajemen Laba: Studi Hermeneutika. Jurnal Akuntansi dan Auditing Indonesia Vol. 4 No. 3.

Rifky, M., Hapsari, D. W., \& Dillak, V. J. (2017). Pengaruh Return On Asset, Net Profit Margin, dan Financial Leverage Terhadap Praktik Perataan Laba. e-Proceeding of Management Vol. 4 No. 1, 380.

Rivai , V. dkk. (2012). Islamic Business and Economic Ethics. Jakarta: Bumi Aksara.

Rivai, V. (2007). Bank dan Financi Institution Management (Conventional and Sharia Sistem). Jakarta: PT Grafindo Persada.

Salno, Hanna, M., \& Zaki, B. (2000, Januari). Analisis Perataan Penghasilan (Income Smoothing): Faktor-Faktor yang Memengaruhi dan Kaitannya dengan Kinerja Saham Perusahaan Publik di Indonesia. Jurnal Riset Akuntansi Indonesia, 17-34.

Sanusi, A. (2011). Metodologi Penelitian Bisnis. Jakarta: Salemba Empat.

Sanusi, A. (2014). Metode Penelitian Bisnis. Jakarta: Salemba Empat.

Sarwono, J. (2016). Prosedur-Prosedur Analisis Populer Aplikasi Riset Skripsi dan Tesis dengan EViews. Yogyakarta: Gava Media.

Setyaningrum, I. S. (2008). Analisis Pengaruh Manajemen Laba (Earning Management) terhadap Kinerja Perusahaan yang Melakukan IPO (Studi pada Perusahaan yang Go-Public di BEJ. Tesis Universitas Sebelas Maret, 3.

Shihab, Q. (1997). Etika Bisnis dalam Wawasan Al-Quran. Jurnal Ulum AlQuran Vol. 7 No. 3.

Sianipar, G. A., \& Marsono. (2013). Analisis Komparasi Kualitas Informasi Akuntansi Sebelum dan Sesudah Pengabdopsian Penuh IFRS di Indonesia. Semarang: Universitas Diponegoro. 
Jurnal Ekonomi dan Perbankan Syariah

Vol. 7. No.1, April 2019: 22-36, ISSN (cet): 2355-1755 | ISSN (online): 25796437

\section{| 35}

Siminica, M., Circiumau, D., \& Simion, D. (2012). The Correlation between the Return On Assets and the Measures of Financial Balance for Romanian Companies. International Journal of Mathematical Models and Methods in Applied Sciences Vol. 6, 249.

Sriyana, J. (2014). Metode Regresi Data Panel. Yogyakarta: Ekonisia.

Sudarma, M., \& Baridwan, Z. (2010). Analisa Praktik Akuntansi Kreatif dalam Konteks Budaya Organisasi PT. Bumi dan Pandangan Islam (Khususnya Ajaran Amanah) dalam Menyikapi Praktik Tersebut. WACANA Vol. 13 No. 33.

Sugiyono. (2016). Metode Penelitian Kuantitatif, Kualitatif, dan R\&D. Bandung: ALFABETA, CV.

Suharyadi, \& Purwanto S.K. (2015). Statistika untuk Ekonomi dan Keuangan Modern (3 ed.). Jakarta: Salemba Empat.

Sulistyanto, H. S. (2008). Manajemen Laba Teori dan Model Empiris. Jakarta: Grasindo.

Sulistyawan, Deddy, \& dkk. (2011). Creative Accounting Mengungkap Manajemen Laba dan Skandal Akuntansi. Jakarta: Salemba Empat.

Suliyanto. (2011). Ekonometrika Terapan: Teori dan Aplikasi dengan SPSS. Yogyakarta: CV. Andi Offset.

Suryani, \& Hendryadi. (2015). Metode Riset Kuantitatif: Teori dan Aplikasi pada Penelitian Bidang Manajemen dan Ekonomi Islam (Edisi ke 1 ed.). Jakarta: Prenada Media Group.

Suryanto, T. (2014). Manajemen Laba pada Bank Syariah di Indonesia: Peran Komite Audit dan Dewan Pengawas Syariah. KINERJA Vol. 18 No. 1.

Suyanto, K. D., \& Supramono. (2012). Likuiditas, Leverage, Komisaris Independen, dan Manajemen Laba terhadap Agresivitas Pajak Perusahaan. Jurnal Keuangan dan Perbankan Vol. 16 No. 2.

Tamuntuan, U. (2015). Analysing The Effect of Return on Equity, Return on Assets and Earning per Share toward Share Price: An Emperical Study of Food and Beverage Companies Listed on Indonesia Stock Exchange). Jurnal Berkala Ilmiah Efisiensi Vol. 15. No. 5, 448.

Triyuwono, I. (1997). Akuntansi Syariah dan Koperasi: Mencari Bentuk dalam Bingkai Metafora Amanah. Jurnal Akuntansi dan Auditing Indonesia Vol.1 No. 1.

Umar, H. (2013). Metode Penelitian untuk Skripsi dan Tesis Bisnis. Jakarta: Rajawali Pers.

Verbeek, M. (2004). A Guide to Modern Economics. England: John Wiley \& Sons Ltd.

Wahyuningsih, I., \& Pujiati, L. (2016). Perbedaan Manajemen Laba pada Bank Syariah dan Bank Konvensional yang Terdaftar di Otoritas Jasa Keuangan. AKADEMIKA Vol. 14 No. 2.

Widarjono, A. (2013). Ekonometrika Pengantar dan Aplikasi (4 ed.). Yogyakarta: UPP STIM YKPN. 
36 | Erika Eriyanti, Rianti Pratiwi, Muhammad Doddy: The Effect of Non-Performing Financing (NPF) on Earnings Management Practices in Islamic and Conventional Bank

Yamin, S., Rachmach, L. A., \& Kurniawan, H. (2011). Regresi dan Korelasi dalam Genggaman Anda. Jakarta: Salemba Empat.

Yanti, \& Safitri. (2011). Pengaruh Faktor-Faktor Fundamental terhadap Harga Saham LQ45 di Bursa Efek Indonesia (BEI). Jurnal Akuntansi STIE $M D P, 1(2), 1-7$. 